ISSN 1678-3921

Journal homepage: www.embrapa.br/pab

For manuscript submission and journal contents, access: www.scielo.br/pab
João Paulo Benedet(1) (iD,

Fernanda Felicetti Perosa(2) (D),

Isabela Gimenes da Silva(2) (DD,

Marcella Zampoli Troncarelli(2) (D),

Ricardo Hummes Rauber( ${ }^{(3)}$ (D) and

Teane Milagres Augusto Gomes ${ }^{(2 \otimes)}$ (iD

(1) Brasil Foods, Concórdia, Rua Senador Atílio Fontana, no 86, Centro, CEP 89700-907 Concórdia, SC, Brazil.

E-mail: jpbenedet@yahoo.com.br

(2) Instituto Federal Catarinense, Campus Concórdia, Escola de Medicina Veterinária, Rodovia SC-283, Vila Fragosos, CEP 89703-720 Concórdia, SC, Brazil. E-mail: fernandaperosa7@gmail.com, isagimenes@hotmail.com, marcella.troncarelli@ifc.edu.br teane.gomes@ifc.edu.br

(3) Brasil Foods, Curitiba, Rodovia CuritibaPonta Grossa Br-277 km 97, Orleans, CEP 82305-100 Curitiba, PR, Brazil. E-mail: ricardo.rauber@brf.com

$\bowtie$ Corresponding author

Received

November 04, 2020

Accepted

November 13, 2020

How to cite BENEDET, J.P.; PEROSA, F.F.; SILVA, I.G. da; TRONCARELLI, M.Z.; RAUBER, R.H.; GOMES, T.M.A. Broiler recycled litter treatments against Clostridium perfringens and enterobacteria in conventional and dark house systems. Pesquisa Agropecuária Brasileira, v. 56 e02325, 2021. DOI: https://doi.org/10.1590/ S1678-3921.pab2021.v56.02325

\section{Broiler recycled litter treatments against Clostridium perfringens and enterobacteria in conventional and dark house systems}

\begin{abstract}
The objective of this work was to evaluate the effectiveness of quicklime and shallow fermentation applications on the reduction of Clostridium perfringens and enterobacteria in recycled poultry litter, in dark house and conventional systems. Eighty litter samples were evaluated, being divided into four groups: litter treated with quicklime in dark house; litter treated with shallow fermentation and quicklime in dark house; and litter treated with quicklime in conventional broiler house; litter treated with shallow fermentation and quicklime in conventional broiler house. Samples were collected one day before slaughter and five days after litter treatment and were subjected to the quantitative microbiological analysis of enterobacteria and C. perfringens. The bacterial load in pre-treated litter was similar between the dark house and conventional systems. The groups treated only with quicklime showed a significant reduction of enterobacteria in both systems. The reduction of $C$. perfringens was only observed in the litter group treated with shallow fermentation and quicklime, in conventional broiler house. The use of $500 \mathrm{~g} \mathrm{~m}^{-2}$ quicklime is the most effective method to reduce enterobacteria load in broiler litter both in the dark house and conventional broiler house systems. The combined treatment of shallow fermentation for seven days with the subsequent application of $500 \mathrm{~g} \mathrm{~m}^{-2}$ quicklime is efficient for the reduction of $C$. perfringens in broiler litter, in conventional broiler house.
\end{abstract}

Index terms: $\alpha$-toxin, aviary, enteric pathogens, Enterobacteriaceae, fermentation, quicklime.

\section{Tratamentos de camas de frango de corte reutilizadas contra Clostridium perfringens e enterobactérias em sistemas convencional e "dark house"}

Resumo - O objetivo deste trabalho foi avaliar a eficácia da aplicação da cal virgem e da fermentação rasa na redução de Clostridium perfringens e enterobactérias em cama de frango de corte reutilizada, nos sistemas "dark house" e convencional. Foram avaliadas 80 amostras de cama, divididas em quatro grupos: cama tratada com cal em "dark house"; cama tratada com fermentação rasa e cal em "dark house"; cama tratada com cal em aviário convencional; e cama tratada com fermentação rasa e cal em aviário convencional. As amostras foram coletadas um dia antes do abate e cinco dias após o tratamento da cama e foram submetidas à análise microbiológica quantitativa de enterobactérias e C. perfringens. A carga bacteriana antes do tratamento foi similar entre os sistemas "dark house" e convencional. Os grupos tratados somente com cal apresentaram redução de enterobactérias em ambos os sistemas. A redução de $C$. perfringens foi observada somente 
no grupo de cama tratada com fermentação rasa e cal em aviário convencional. O uso de $500 \mathrm{~g} \mathrm{~m}^{-2}$ de cal virgem é o método mais eficaz para reduzir a carga de enterobactérias em cama de frango, tanto no sistema "dark house" como no convencional. O tratamento combinado de fermentação rasa por sete dias com a posterior aplicação de $500 \mathrm{~g} \mathrm{~m}^{-2}$ de cal é eficiente para a redução de C. perfringens, em cama de frango, em aviário convencional.

Termos para indexação: $\alpha$-toxina, aviário, patógenos entéricos, Enterobacteriaceae, fermentação, cal.

\section{Introduction}

Brazil is the third greatest producer and the greatest exporter of broiler meat, distributing this product to more than 140 countries. The current broiler industry in this country provides a constant evolution regarding productivity, product quality and safety, and sanitary status of flocks (ABPA, 2018).

In 1997, the World Health Organization published a report linking the use of antibiotics in animal feed and the increase of the antimicrobial resistance in the human population (WHO, 1997). Thus, the European Union has banned, in 2006, any antibiotic or chemotherapeutics that were used as feed additives for the improvement of animal production performance (European Parliament and of the Council, 2003). The withdrawal of antimicrobial growth promoters has caused intestinal microbiota imbalance, and increased the enteric challenges and diseases in broilers, generating health, zootechnical, and economical losses (Maiorka, 2004; Van Immerseel et al., 2004; Timbermont et al., 2011; M'Sadeq et al., 2015).

Among enteric microorganisms, there are two main groups which infect broilers: enterobacteria, including various bacteria genera that are eliminated with excreta and may compose the microbiota of the litter (Cressman et al., 2010; Vaz et al., 2017); and toxin-producing Clostridium perfringens that are associated to necrotic enteritis in broilers (Gomes et al., 2008; Albornoz et al., 2014; Li et al., 2017), leading to depression, lack of appetite, apathy, prostration, dehydration, and death (Timbermont et al., 2011). Acute clinical outbreaks of necrotic enteritis may cause high levels of mortality (Van Immerseel et al., 2004; Albornoz et al., 2014), and the persistent subclinical disease in broiler flocks leads to a significant economic impact (Løvland
\& Kaldhusdal, 1999). Moreover, productivity losses such as decreased nutrient uptake, poor feed conversion ratio, and low weight gain are described in subclinical cases of necrotic enteritis (Timbermont et al., 2011).

Infectious agents may remain in broiler litter after its reuse between flocks, which is a current practice in broiler farming (Cressman et al., 2010). Because of litter initial cost, the same ones are used for up to two or three years, to raise several broiler flocks, before they are completely removed (Dai Prá \& Roll, 2012; Lopes et al., 2013). Therefore, it is extremely important that an effective treatment is carried out before reusing litter, to avoid pathogen contamination between flocks.

According to official guidelines in Brazil, litter reuse between flocks is allowed, as long as there is no potential risk to the next flock or to public health (Brasil, 2007). The most commonly used treatments in Brazilian broiler farms include: the application of quicklime to the litter; and fermentative methods, such as windrow in the center of the broiler house, and shallow fermentation throughout the broiler house (Dai Prá \& Roll, 2012; Lopes et al., 2013, 2015; Vaz et al., 2017).

In Brazil, many broiler houses are still conventional systems, with the use of fans and sidewall curtains (Abreu \& Abreu, 2011). However, in the last years, the number of broiler houses built and transformed into dark house system has increased. Dark house has an insulated, fan-ventilated environment, controlled by evaporative cooling system, to handle climate control (Carvalho et al., 2015). Furthermore, there is evidence that the dark house system provides better weight gain, improved feed conversion, and fewer stress levels than the conventional broiler house (Carvalho et al., 2015; Cristo et al., 2017).

Many studies evidence the effects of the dark house system on animal welfare, zootechnical performance, and gas emission (Lima et al., 2011; Carvalho et al., 2015; Cristo et al., 2017); however, fewer studies have evaluated the litter microbiological quality in this system.

The objective of this work was to evaluate the effectiveness of quicklime and shallow fermentation applications on the reduction of $C$. perfringens and enterobacteria in recycled broiler litter, in dark house and conventional systems. 


\section{Materials and Methods}

Selected broiler houses were located in the Western Santa Catarina state, and they had more than one broiler house in the same property. In total, 40 broiler houses were evaluated, from which 16 were of dark house system, and 24 of conventional system. The main differences between the broiler houses used in this experiment are described below.

In the conventional broiler houses, the internal temperature was controlled by using fans and opening or closing the sidewall curtains; however, climate oscillations were expected due to environmental temperature variation. In the dark house, black sidewall curtains were kept closed, to produce negative pressure, and the internal temperature was controlled with an evaporative pad cooling system and fanventilated environment. Also, the number of broilers housed differed according to the broiler house system, with 12 broilers $\mathrm{m}^{-2}$ in the conventional broiler houses, and 14 broilers $\mathrm{m}^{-2}$ in the dark houses.

All selected broiler houses had reused litters 4 to 14 times, and were equally distributed among the treated groups: 17 litters $(42.5 \%)$ reused 4 to 6 times; 12 litters (30\%) reused 7 to 9 times; and 11 litters $(27.5 \%)$ reused 10 to 14 times. Furthermore, all litters used in this experiment were previously treated with quicklime $\left(500 \mathrm{~g} \mathrm{~m}^{-2}\right)$.

After removing broilers for slaughter at 40 days of age, the poultry farmer removed the caked litter, when present, and burned the feathers before the treatment. Two litter treatments were evaluated: the application of $500 \mathrm{~g} \mathrm{~m}^{-2}$ of quicklime of broiler litter; and shallow fermentation of the litter for 7 days, followed by quicklime application $\left(500 \mathrm{~g} \mathrm{~m}^{-2}\right)$. The quicklime application was performed using a spreader cart, followed by its homogeneous distribution throughout the litter. For the shallow fermentation treatment, the plastic tarpaulin was extended on the entire litter of the broiler house (not placing it between the edge of the litter and the wall of the broiler house), remaining in fermentation process during 7 days. After that, quicklime application was performed $\left(500 \mathrm{~g} \mathrm{~m}^{-2}\right)$. Despite the type of litter treatment, all broiler houses were subjected to 16 days of downtime between flocks.

In total, 80 litter samples were collected in 40 broiler houses. The first sample $(n=40)$ was collected one day before broilers' slaughter, and the second sample $(\mathrm{n}=40)$ was collected 5 days after quicklime application. Each sample consisted of a pool of litter collected at 16 equidistant points from each other along the broiler house.

At each point, approximately $40 \mathrm{~g}$ of litter was collected at $5 \mathrm{~cm}$ depth from the surface. Each sample was equally divided into two sampling bags (3M do Brasil, Sumaré, SP, Brazil) containing, in total, approximately $320 \mathrm{~g}$ of litter, which were maintained under refrigeration $\left(2^{\circ} \mathrm{C}\right.$ to $\left.8^{\circ} \mathrm{C}\right)$ for the microbiological analysis, which was performed on the next day.

The samples were divided into four groups: litter treated with quicklime in dark house $(n=8)$; litter treated with shallow fermentation and quicklime in dark house $(n=8)$; litter treated with quicklime in conventional system $(\mathrm{n}=12)$; litter treated with shallow fermentation and quicklime in conventional system $(\mathrm{n}=12)$.

For the microbiological analysis, the litter samples were homogenized in a sampling bag, dissolved in PBS (1:10), and homogenized at $200 \mathrm{rpm}$, at $25^{\circ} \mathrm{C}$ for $10 \mathrm{~min}$. For the enterobacteria quantitative analysis, samples subjected to serial decimal dilutions were plated in duplicate in MacConkey agar and incubated at $37^{\circ} \mathrm{C}$ for 24 hours (Vaz et al., 2017). Pink (lactose fermenter) and colorless (lactose nonfermenter) colonies were counted. For $C$. perfringens quantitative analysis, samples subjected to serial decimal dilutions were plated in duplicate in sulfite polymyxin sulfadiazine selective medium (SPS, Merck Sharp \& Dohme, Kenilworth, NJ, USA) and incubated in anaerobic jar at $37^{\circ} \mathrm{C}$, for at least 48 hours, according to Schocken-Iturrino et al. (2010). Only black colonies (sulfite reducers) were counted. The detection limit for both enterobacteria and $C$. perfringens was $100 \mathrm{CFU}$ $\mathrm{g}^{-1}$ of litter sample.

For the detection of $C$. perfringens cpa gene, which encodes the $\alpha$-toxin, a pool of colonies isolated in SPS medium from each littersample $(\mathrm{n}=67)$ was resuspended in $100 \mu \mathrm{L}$ sterile distilled water. The DNA extraction was performed by boiling at $100^{\circ} \mathrm{C}$ for $10 \mathrm{~min}$, followed by centrifugation at $1,000 \mathrm{x} g$ for $5 \mathrm{~min}$. Specific primers Fwd: 5'-TGCATGAGCTTCAATTAGGT-3' and Rev: 5'-TTAGTTTTGCAACCTGCTGT-3' were used to amplify the cpa gene, with a final product of $400 \mathrm{bp}$ (Heikinheimo \& Korkeala, 2005). Each PCR reaction contained $23 \mu \mathrm{L}$ Supermix (Invitrogen, São Paulo, SP, Brazil), $0.5 \mu \mathrm{L}$ of each primer $\left(25 \mu \mathrm{mol} \mathrm{L}^{-1}\right), 1 \mathrm{U}$ of Taq polymerase (Ludwig Biotecnologia, Alvorada, 
$\mathrm{RS}$, Brazil), and $2 \mu \mathrm{L}$ of DNA. The thermocycler amplification protocol was: denaturation for $5 \mathrm{~min}$ at $95^{\circ} \mathrm{C} ; 35$ cycles of $1 \mathrm{~min}$ at $94^{\circ} \mathrm{C}, 1 \mathrm{~min}$ at $53^{\circ} \mathrm{C}$, and $1 \mathrm{~min}$ at $72^{\circ} \mathrm{C}$; and the final extension for $10 \mathrm{~min}$ at $72^{\circ} \mathrm{C}$. Subsequently, the isolates were subjected to $1.5 \%$ agarose gel electrophoresis. As positive control, a field isolate of $C$. perfringens was used.

All CFU (colony-forming unit) data were logarithmically transformed $\left(\log _{10}\right)$, expressed as means and standard deviations, and subjected to statistical analysis by unpaired t-test (GraphPad InStat 3). P-values of less than 0.05 were considered significant.

\section{Results and Discussion}

The quicklime application to both dark house and conventional broiler house promoted a significant reduction of enterobacteria CFU values $(p<0.05)$ after the litter treatments (Table 1). The use of quicklime showed to be more efficient in reducing the enterobacteria than the combination of shallow fermentation with subsequent application of the quicklime.

Regarding $C$. perfringens, only the combined treatment of shallow fermentation and subsequent quicklime application to the conventional system significantly reduced $(\mathrm{p}<0.05)$ the CFU values after the litter treatment (Table 2). However, all groups showed reduced $C$. perfringens $\mathrm{CFU}$ values before treatment, regardless of the broiler house system and litter treatment used.

In the present study, the CFU values of C.perfringens found in the litters were lower than those described by Cressman et al. (2010); however, the authors did not assess previous litter treatment between flocks. Furthermore, low $\mathrm{CFU} \mathrm{g}{ }^{-1}$ values of $C$. perfringens in the litters were evidenced before the treatments, showing the positive effect of biosecurity procedures. These data corroborate with those for the absence of disease in the evaluated flocks, as the integrated company of all broiler houses (451 conventional and 200 dark houses) had neither a clinical case of necrotic enteritis nor a laboratory diagnosis of toxin-producing C. perfringens strains during the same year.

The presence of cpa toxigenic gene was verified by conventional PCR in litter samples with viable $C$. perfringens count. From 67 C. perfringens positive litter samples, the cpa gene was detected in 10 isolates, which were equally distributed before and after litter treatments (Table 3). These results show a low percentage of $C$. perfringens isolates with cpa gene. From all 35 broiler houses positive for $C$. perfringens

Table 1. Enterobacteria count $\left(\log _{10} \mathrm{CFU} \mathrm{g} \mathrm{g}^{-1}\right)$ in litters of dark house and conventional broiler houses treated with shallow fermentation and/or quicklime.

\begin{tabular}{|c|c|c|c|c|c|c|}
\hline \multirow[t]{2}{*}{ Broiler house } & \multirow[t]{2}{*}{ Litter treatment } & \multicolumn{2}{|c|}{ Enterobacteria count before treatment } & \multicolumn{2}{|c|}{ Enterobacteria count after treatment } & \multirow[t]{2}{*}{ p-value } \\
\hline & & Mean & Standard deviation & Mean & Standard deviation & \\
\hline \multirow{2}{*}{ Dark house } & Quicklime & 3.20 & 1.13 & 2.04 & 0.11 & $<0.05$ \\
\hline & Fermentation + quicklime & 3.05 & 1.56 & 2.78 & 1.14 & $>0.05$ \\
\hline \multirow{2}{*}{ Conventional } & Quicklime & 3.50 & 1.27 & 2.48 & 0.88 & $<0.05$ \\
\hline & Fermentation + quicklime & 2.96 & 1.23 & 2.17 & 0.58 & $>0.05$ \\
\hline
\end{tabular}

Table 2. Clostridium perfringens count $\left(\log _{10} \mathrm{CFU} \mathrm{g}{ }^{-1}\right)$ in litters of dark house and conventional broiler houses treated with shallow fermentation and/or quicklime.

\begin{tabular}{|c|c|c|c|c|c|c|}
\hline \multirow[t]{2}{*}{ Broiler house } & \multirow[t]{2}{*}{ Litter treatment } & \multicolumn{2}{|c|}{ C. perfringens count before treatment } & \multicolumn{2}{|c|}{ C. perfringens count after treatment } & \multirow[t]{2}{*}{ p-value } \\
\hline & & Mean & Standard deviation & Mean & Standard deviation & \\
\hline \multirow{2}{*}{ Dark house } & Quicklime & 2.30 & 0.42 & 2.21 & 0.53 & $>0.05$ \\
\hline & Fermentation + quicklime & 2.33 & 0.41 & 2.08 & 0.17 & $>0.05$ \\
\hline \multirow{2}{*}{ Conventional } & Quicklime & 2.29 & 0.34 & 2.23 & 0.47 & $>0.05$ \\
\hline & Fermentation + quicklime & 2.33 & 0.36 & 2.04 & 0.14 & $<0.05$ \\
\hline
\end{tabular}


before treatment, only two conventional broiler houses, one treated with quicklime and the other with both shallow fermentation and quicklime, were also positive for the cpa gene after treatment. In the other six broiler houses, the toxigenic gene was detected before or after litter treatment.

Cpa was previously detected by PCR as being the only lethal toxin-encoded gene in $60.8 \%$ of $C$. perfringens isolates from intestinal content of broilers. These isolates were characterized as $C$. perfringens type A, which was one of the most prevalent toxigenic type recovered from the jejunum and ileum of broilers (Gomes et al., 2008). Additionally, other two studies have shown that all $C$. perfringens isolates recovered from broiler's intestine carry the cpa gene (Heikinheimo \& Korkeala, 2005; Li et al., 2017), and that most of these isolates are sufficiently virulent to produce enteric disease in broilers coinfected with other enteric pathogens such as Eimeria spp. (Albornoz et al., 2014; Li et al., 2017).

The amplification of cpa gene indicates a potential risk of occurring necrotic enteritis in broilers, considering that this gene encodes the $\alpha$-toxin, which is conserved in all types of toxigenic $C$. perfringens that affect broilers (Heikinheimo \& Korkeala, 2005). This toxin can cause the hydrolysis of the phospholipid portion of the cell membrane and lysis of the cells. Consequently, these lesions lead to loss of the intestinal mucosa integrity, affecting the absorption capacity of the cells and, therefore, causing significant economic losses (Van Immerseel et al., 2004; Timbermont et al., 2011; Albornoz et al., 2014).

The presence of residual bacteria in the litter is a critical threat to animal health during litter recycling between flocks (Dai Prá \& Roll, 2012; Lopes et al., 2013; Ritz et al., 2014; GlobalGAP, 2019). In the present study, quicklime litter treatment was efficient to reduce enterobacteria in both dark house and conventional broiler houses. This result was similar to that described by Dai Pra et al. (2009), which used $300 \mathrm{~g}$ of quicklime $\mathrm{m}^{-2}$ of litter for Salmonella spp. control in reused litter after one flock. A suggested antimicrobial effect of quicklime is due to the high $\mathrm{pH}$ and dehydration of the broiler litter over the course of the flocks (Dai Pra et al., 2009; Chen \& Jiang, 2014); however, low quicklime concentrations applied to different litter composition may not significantly reduce the bacterial load (Bennett et al., 2005; Chen \& Jiang, 2014; Ritz et al., 2014).

Additionally, a previous study has shown that shallow fermentation in conventional broiler houses was more efficient than quicklime and windrowing treatments, for reducing bacterial load of enterobacteria and aerobic mesophiles in reused litters throughout six consecutive flocks (Vaz et al., 2017). These results differ from those of the present study, which evaluated litters reused at least four times. Although field litter samples showed a variety of reuse, it is known that untreated broiler litters reach a stabilized bacterial load of enterobacteria and mesophiles from the fourth flock onward (Vaz et al., 2017), as well as a decreased bacterial load of Salmonella spp. after the sixth reuse of the litter (Roll et al., 2011).

Litter treatments in conventional broiler houses during downtime period can be based on the sanitary challenge that each broiler house has, since, for enterobacteria, the most effective treatment was the quicklime application, whereas against C. perfringens, the most effective treatment was shallow fermentation and subsequent quicklime application. Conversely, the latter is more laborious because seven days are necessary for shallow fermentation, followed by

Table 3. Detection of cpa toxigenic gene by conventional PCR in Clostridium perfringens isolates of broiler litters.

\begin{tabular}{lcc}
\hline Broiler house - litter treatment & \multicolumn{2}{c}{ Detection of cpa toxigenic gene $(\%)$} \\
\hline Dark house - quicklime & Before treatment ${ }^{(1)}$ & After treatment ${ }^{(1)}$ \\
Dark house - fermentation + quicklime & $14.3(1,7)$ & $16.7(1,6)$ \\
Conventional - quicklime & $0.0(0,7)$ & $0.0(0,7)$ \\
Conventional - fermentation + quicklime & $22.2(2,9)$ & $33.3(3,9)$ \\
\hline Total (broiler houses) & $16.7(2,12)$ & $10.0(1,10)$ \\
\hline
\end{tabular}

(1) Number of positive and total litter samples between parentheses $($,$) .$ 
quicklime treatment. In addition, this leaves a short period after litter treatment to prepare the broiler house for housing chicks. These results reinforce the important role of monitoring pathogens in broiler litters and, therefore, determining the potential health risks for broilers. This helps to decide which health program will be best applied, contributing to improve biosecurity programs in different broiler houses.

\section{Conclusions}

1. The use of $500 \mathrm{~g} \mathrm{~m}^{-2}$ of quicklime is the most effective method for reducing enterobacteria load in broiler litter, in both dark house and conventional broiler house systems.

2. The combined treatment of shallow fermentation for 7 days with the subsequent application of $500 \mathrm{~g} \mathrm{~m}^{-2}$ of quicklime is efficient for the reduction of Clostridium perfringens in broiler litter, in conventional broiler house.

\section{References}

ABPA. Associação Brasileira de Proteína Animal. Relatório anual 2018. São Paulo, 2018. p.176. Available at: <http://abpabr.com.br/storage/files/relatorio-anual-2018.pdf $>$. Accessed on: May 102018.

ABREU, V.M.N.; ABREU, P.G. de. Os desafios da ambiência sobre os sistemas de aves no Brasil. Revista Brasileira de Zootecnia, v.40, p.1-14, 2011. Suplemento especial. Available at: $<$ https:// www.embrapa.br/busca-de-publicacoes/-/publicacao/901939/osdesafios-da-ambiencia-sobre-os-sistemas-de-aves-no-brasil>. Accessed on: Aug. 102020.

ALBORNOZ, L.A.L.; NAKANO, V.; AVILA-CAMPOS, M.J. Clostridium perfringens e a enterite necrótica em frangos: principais fatores de virulência, genéticos e moleculares. Brazilian Journal of Veterinary Research Animal Science, v.51, p.178-193, 2014. DOI: https://doi.org/10.11606/issn.16784456.v51i3p178-19.

BENNETT, D.S.; HIGGINS, S.E.; MOORE, R.; BYRD, J.A.; BELTRAN, R.; CORSIGLIA, C.; CALDWELl, D.; HARGIS, B.M. Effect of addition of hydrated lime to litter on recovery of selected bacteria and poultry performance. Journal of Applied Poultry Research, v.14, p.721-727, 2005. DOI: https://doi.org/10.1093/japr/14.4.721.

BRASIL. Ministério da Agricultura, Pecuária e Abastecimento. Instrução Normativa $n^{\circ} 56$, de 4 de dezembro de 2007. [Estabelece os procedimentos para registro, fiscalização e controle de estabelecimentos avícolas de reprodução e comerciais]. Diário Oficial da União, 6 dez. 2007. Seção1, p.11-16.

CARVALHO, R.H.; SOARES, A.L.; GRESPAN, M.; SPURIO, R.S.; CORÓ, F.A.G.; OBA, A.; SHIMOKOMAKI, M. The effects of the dark house system on growth, performance and meat quality of broiler chicken. Animal Science Journal, v.86, p.189193, 2015. DOI: https://doi.org/10.1111/asj.12262.

CHEN, Z.; JIANG, X. Microbiological safety of chicken litter or chicken litter-based organic fertilizers: a review. Agriculture, v.4, p.1-29, 2014. DOI: https://doi.org/10.3390/agriculture4010001.

CRESSMAN, M.D.; YU, Z.; NELSON, M.C.; MOELLER, S.J.; LILBURN, M.S.; ZERBY, H.N. Interrelations between the microbiotas in the litter and in the intestines of commercial broiler chickens. Applied and Environmental Microbiology, v.76, p.6572-6582, 2010. DOI: https://doi.org/10.1128/AEM.00180-10.

CRISTO, A.B. de; SCHIMIDT, J.M.; PERINI, R.; MORA, M.; MARQUES, P.F. dos S.; SANTOS, A.L. dos; FERNANDES, J.I.M. Efeito da densidade de alojamento sobre a incidência de pododermatite e características ósseas de frangos de corte criados em aviários Dark House. Revista Brasileira de Saúde e Produção Animal, v.18, p.161-173, 2017. DOI: https://doi.org/10.1590/s1519-99402017000100015.

DAI PRA, M.A.; CORREA, E.K.; ROLL, V.F.; XAVIER, E.G.; LOPES, D.C.N.; LOURENÇO, F.F.; ZANUSSO, J.T.; ROLL, A.P. Uso de cal virgem para o controle de Salmonella spp. e Clostridium spp. em camas de aviário. Ciência Rural, v.39, p.1189-1194, 2009. DOI: https://doi.org/10.1590/S0103-84782009005000028.

DAI PRÁ, M.A.; ROLL, V.F.B. (Org.). Cama de aviário: utilização, reutilização e destino. Porto Alegre: Manas, 2012. 86p.

EUROPEAN PARLIAMENT AND OF THE COUNCIL. Regulation $n^{\circ}$ 1831, de September 22, 2003. On additives for use in animal nutrition. Available at: $<$ https://eur-lex.europa.eu/legalcontent/PT/TXT/PDF/?uri=CELEX:32003R1831\&from=EN $>$. Accessed on: Apr. 52018.

GLOBALG.A.P. Integrated farm assurance: all farm base: livestock base - poultry. Version 5.2. Cologne, 2019. Available at: <https://www.globalgap.org/.content/galleries/ documents/190201_GG_IFA_CPCC_PY_V5_2_en.pdf $>$. Accessed on: Nov. 26 2019.

GOMES, A. de M.; LOBATO, F.C.F.; MARTINS, N.R. da S.; ASSIS, R.A. de. Genotipicação de Clostridium perfringens isolados de frangos de corte através da PCR múltipla. Ciência Rural, v.38, p.1943-1947, 2008. DOI: https://doi.org/10.1590/ S0103-84782008000700022.

HEIKINHEIMO, A.; KORKEALA, H. Multiplex PCR assay for toxinotyping Clostridium perfringens isolates obtained from Finnish broiler chickens. Letters in Applied Microbiology, v.40, p.407-411, 2005. DOI: https://doi.org/10.1111/j.1472765X.2005.01702.x.

LI, C.; LILLEHOJ, H.S.; GADDE, U.D.; RITTER, D.; OH, S. Characterization of Clostridium perfringens strains isolated from healthy and necrotic enteritis-afflicted broiler chickens. Avian Disease, v.61, p.178-185, 2017. DOI: https://doi.org/10.1637/11507093016-Reg.1.

LIMA, K.A.O.; MOURA, D.J.; CARVALHO, T.M.R.; BUENO, L.G.F.; VERCELLINO, R.A. Ammonia emissions in tunnelventilated broiler houses. Brazilian Journal of Poultry Science, v.13, p.265-270, 2011. DOI: https://doi.org/10.1590/S1516$635 \times 2011000400008$. 
LOPES, M.; LEITE, F.L.; VALENTE, B.S.; HERES, T.; DAI PRÁ, M.A.; XAVIER, E.G.; ROLL, V.F.B. An assessment of the effectiveness of four in-house treatments to reduce the bacterial levels in poultry litter. Poultry Science, v.94, p.2094-2098, 2015. DOI: https://doi.org/10.3382/ps/pev195.

LOPES, M.; ROLL, V.F.B.; LEITE, F.L.; DAI PRÁ, M.A.; XAVIER, E.G.; HERES, T.; VALENTE, B.S. Quicklime treatment and stirring of different poultry litter substrates for reducing pathogenic bacteria counts. Poultry Science, v.92, p.638-644, 2013. DOI: https://doi.org/10.3382/ps.2012-02700.

LØVLAND, A.; KALDHUSDAL, M. Liver lesions seen at slaughter as an indicator of necrotic enteritis in broiler flocks. FEMS Immunology and Medical Microbiology, v.24, p.345351, 1999. DOI: https://doi.org/10.1111/j.1574-695X.1999. tb01304.x.

MAIORKA, A. Impacto da saúde intestinal na produtividade avícola. In: SIMPÓSIO BRASIL SUL DE AVICULTURA, 5., 2004, Chapecó. Anais. Concórdia: Embrapa-CNPSA, 2004. p.119-129.

M'SADEQ, S.A.; WU, S.; SWICK, R.A.; CHOCT, M. Towards the control of necrotic enteritis in broiler chickens with in-feed antibiotics phasing-out worldwide. Animal Nutrition, v.1, p.1-11, 2015. DOI: https://doi.org/10.1016/j.aninu.2015.02.004.

RITZ, C.W.; FAIRCHILD, B.D.; LACY, M.P. Litter quality and broiler performance. University of Georgia Extension Bulletin, v.1267, p.1-8, 2014. Available at: $<$ https://extension.uga. edu/publications/detail.html? number $=$ B1267\& title $=$ Litter $\% 20$ Quality\%20and\%20Broiler\%20Performance>. Accessed on: May 222018.
ROLL, V.F.B.; DAI PRÁ, M.A.; ROLL, A.P. Research on Salmonella in broiler litter reused for up to 14 consecutive flocks. Poultry Science, v.90, p.2257-2262, 2011. DOI: https://doi.org/10.3382/ps.2011-01583.

SCHOCKEN-ITURRINO, R.P.; VITTORI, J.; BERALDOMASSOLI, M.C.; DELPHINO, T.P.C.; DAMASCENO, P.R. Clostridium perfringens em rações e águas fornecidos a frangos de corte em granjas avícolas do interior paulista - Brasil. Ciência Rural, v.40, p.197-199, 2010. DOI: https://doi.org/10.1590/S010384782010000100033.

TIMBERMONT L.; HAESEBROUCK, F.; DUCATELLE, R.; VAN IMMERSEEL, F. Necrotic enteritis in broilers: an updated review on the pathogenesis. Avian Pathology, v.40, p.341-347, 2011. DOI: https://doi.org/10.1080/03079457.2011.590967.

VAN IMMERSEEL, F.; DE BUCK, J.; PASMANS, F.; HUYGHEBAERT, G.; HAESEBROUCK, F.; DUCATELLE, R. Clostridium perfringens in poultry: an emerging threat for animal and public health. Avian Pathology, v.33, p.537-549, 2004. DOI: https://doi.org/10.1080/03079450400013162.

VAZ, C.S.L.; VOSS-RECH, D.; AVILA, V.S. de; COLDEBELLA, A.; SILVA, V.S. Interventions to reduce the bacterial load in recycled broiler litter. Poultry Science, v.96, p.2587-2594, 2017. DOI: https://doi.org/10.3382/ps/pex063.

WHO. World Health Organization. The medical impact of antimicrobial use in food animals. 1997. WHO/EMC/ ZOO/97.4. Available at: <https://apps.who.int/iris/bitstream/ handle/10665/64439/WHO_EMC_ZOO_97.4.pdf > . Accessed on: Apr. 52018. 